\title{
Glaciological and climatic significance of Hercules Dome, Antarctica: An optimal site for deep ice core drilling
}

\author{
Robert W. Jacobel and Brian C. Welch \\ Department of Physics, St. Olaf College, Northfield, Minnesota, USA
}

Eric J. Steig and David P. Schneider

Department of Earth and Space Sciences and Quaternary Research Center, University of Washington, Seattle, Washington, USA

Received 16 June 2004; revised 5 January 2005; accepted 25 January 2005; published 24 March 2005.

[1] We present glaciological and climatological characteristics of Hercules Dome, Antarctica $\left(86^{\circ} \mathrm{S}, 105^{\circ} \mathrm{W}\right)$, which demonstrate its potential as a deep ice core site. Annual layering in $\delta D$ ratios from a $72 \mathrm{~m}$ ice core collected by the US-ITASE 2002 traverse indicate accumulation rates of $0.16-0.20 \mathrm{~m} / \mathrm{yr}$ ice equivalent over the last 300 years. Age control from stratigraphy seen in the radio-echo sounding data collected during the same traverse suggests a rate of $0.09-0.11 \mathrm{~m} / \mathrm{yr}$ averaged over the past 18,000 years. Ice stratigraphy also indicates that the ice divide position has been stable through at least this period. Comparison of satellite-derived temperature anomalies with atmospheric reanalysis data show that the site is sensitive to the two dominant patterns of climate variability in the high-latitude Southern Hemisphere. Climate proxy data from a deep ice core at Hercules Dome would be indicative of changes in Pacific Southern Hemisphere climate variability and may provide new information on rapid climate change events in Antarctica. The sensitivity of the site and the combination of relatively high accumulation rates, low temperatures (mean annual $-35^{\circ} \mathrm{C}$ to $-40^{\circ} \mathrm{C}$ ), and simple ice flow suggest that Hercules Dome is an ideal site for a future deep ice core.

Citation: Jacobel, R. W., B. C. Welch, E. J. Steig, and D. P. Schneider (2005), Glaciological and climatic significance of Hercules Dome, Antarctica: An optimal site for deep ice core drilling, J. Geophys. Res., 110, F01015, doi:10.1029/2004JF000188.

\section{Introduction}

[2] In this paper, we present an assessment of prospects for deep ice coring at Hercules Dome based on results from GPS, ice-penetrating radar profiles and stable isotope measurements from a $72 \mathrm{~m}$ ice core acquired as part of the U.S. portion of the International Trans-Antarctic Scientific Expedition (ITASE) traverse. Hercules Dome $\left(86^{\circ} \mathrm{S}, 105^{\circ} \mathrm{W}\right)$, is an elongated approximately $100 \mathrm{~m}$ local rise in the ice surface topography between the Horlick and Thiel Mountains about $400 \mathrm{~km}$ from South Pole. We highlight three specific motivations for considering Hercules Dome as a deep ice core site: (1) Antarctic ice sheet dynamics, (2) Antarctic climate variability, and (3) rapid climate change.

[3] First, Hercules Dome is glaciologically interesting because it is located approximately $150 \mathrm{~km}$ up-flow from "The Bottleneck," where ice is funneled from the East Antarctic Ice Sheet (EAIS) to the West Antarctic Ice Sheet (WAIS) (Figure 1a). This makes it potentially valuable as an indicator of changes in ice elevation associated with both the EAIS and the more dynamic WAIS in response to sea level and climate forcing. The issue of elevation changes for

Copyright 2005 by the American Geophysical Union. 0148-0227/05/2004JF000188\$09.00 the two ice sheets is a critical one glaciologically since a number of problems related to the dynamics of ice flow in Antarctica are tied to the magnitude of these changes. A great deal has been written about past changes in WAIS elevation [e.g., Raynaud and Whillans, 1982; Ackert et al., 1999; Steig et al., 2001], but changes to the EAIS are less well constrained and the only information currently available regarding EAIS elevation change is from Vostok [e.g., Martinérie et al., 1994]. Sitting just upstream of the bottleneck, Hercules Dome should be sensitive to elevation changes controlling flow from the EAIS to the WAIS.

[4] A second motivation for a deep ice core at Hercules Dome lies in improving our knowledge of past Antarctic climate variability. Antarctic climate is sufficiently complex that records from multiple locations are needed to adequately characterize it. For example, temperature records from meteorological stations in East Antarctica have generally shown summer cooling and winter warming over the last few decades, while stations on the Antarctic Peninsula have warmed in all seasons [Vaughan et al., 2003]. Ice core records give some indication that similar spatial complexity may persist on longer timescales: the expression of the Little Ice Age in Antarctica appears to have included warming in some areas and cooling in others [Steig and Schneider, 2002; Mosley-Thompson and Thompson, 1991]. However, these results are limited due to the relatively low 
a)
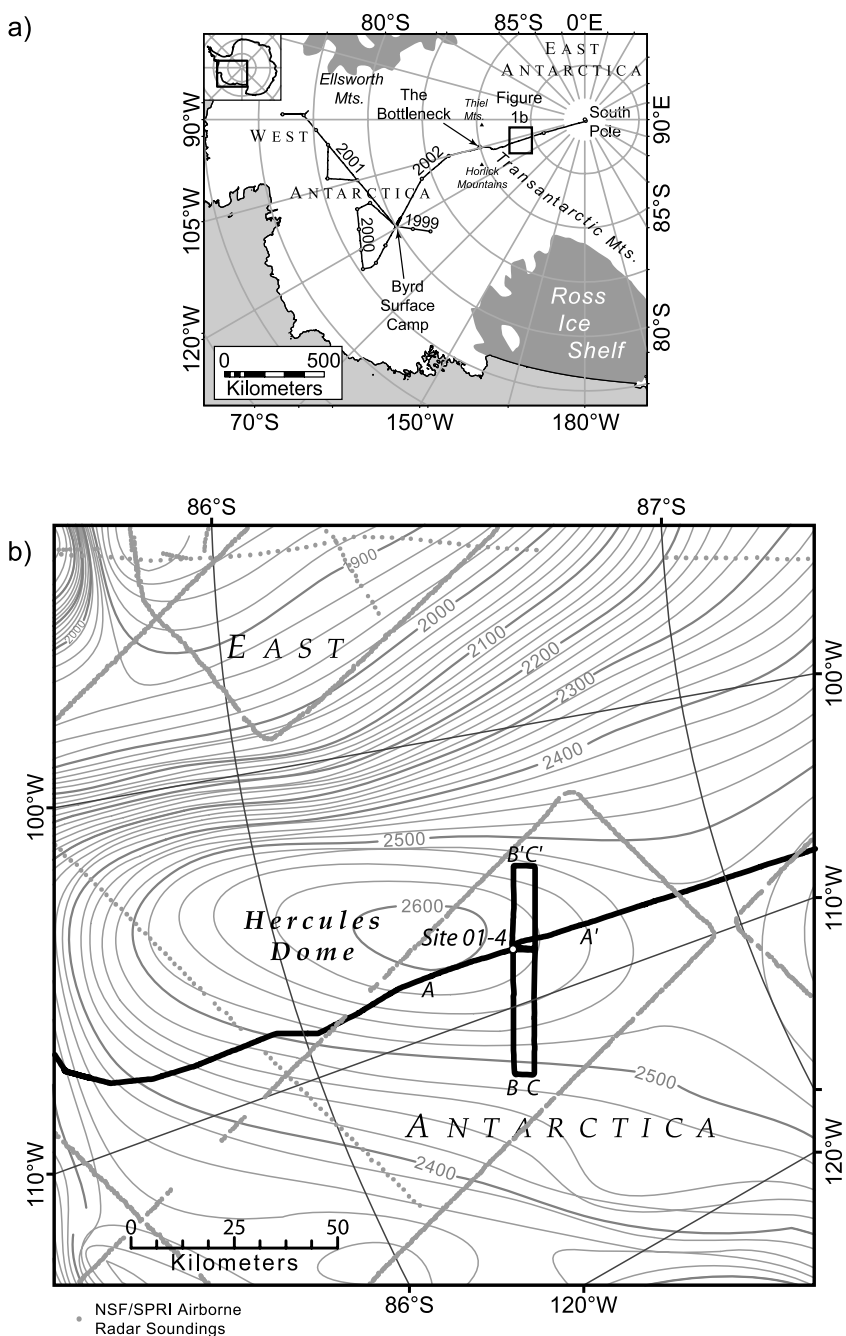

Figure 1. (a) Area map showing US-ITASE routes from 1999 to 2002. The 2002 traverse begins at Byrd Station and passes between the Thiel and Horlick Mountains, "The Bottleneck," before crossing Hercules Dome (box) and ending at South Pole Station. (b) Hercules Dome and vicinity with surface contours based on the RAMP digital elevation model (DEM) [Liu et al., 1999]. US-ITASE main traverse route and radar grid lines are indicated with bold lines. Flight lines from the NSF/SPRI airborne soundings used to develop the BEDMAP bedrock map [Lythe et al., 2001] are shown as shaded dots.

resolution and spatial coverage of the available ice cores. Hercules Dome is of particular interest in this context because it is from a largely unsampled region of the ice sheet, roughly two-thirds of the way between Byrd Station $\left(80^{\circ} \mathrm{S} 120^{\circ} \mathrm{W}\right)$ and South Pole.

[5] Finally, an ice core from Hercules Dome could contribute substantially to the study of rapid climate change. The documentation of rapid climate change events during the last glacial period in central Greenland ice cores is well known, and the most direct evidence is found in the anomalies detected in isotopic and molecular ratios of atmospheric trace gases trapped in air bubbles [e.g., Severinghaus and Brook, 1999]. To date, the only evidence for such anomalies in Antarctica is a single event at
Siple Dome occurring at about $20 \mathrm{ka}$ [Taylor et al., 2004]. However, preservation of these anomalies, which are quite short lived, requires relatively high snow accumulation rates; the very low accumulation rates at other East Antarctic sites such as Dome $\mathrm{C}$ and Vostok $(<0.03 \mathrm{~m} / \mathrm{a}$ ice equivalent) would prevent all but the largest anomalies from being preserved [Caillon et al., 2003]. It is therefore possible that such events have been more widespread in Antarctica, but have not been documented.

[6] Hercules Dome was first identified by the U.S. Geological Survey from U.S. Navy aerial photographs taken in 1959-1960 and further delineated by the SPRI-NSF-TUD airborne radio echo-sounding program in 1967-1979. It was first discussed in the late 1980 s by the U.S. National Science Foundation-sponsored Ice Core Working Group as a possible site for a deep ice core [Ice Core Working Group $(I C W G), 1988,1989]$. Interest in Hercules Dome has recently been rekindled by the US-ITASE traverse which has provided the first ground-based observations of the area. ITASE is a multinational effort to characterize the last 2002000 years of climate throughout Antarctica [Mayewski and Goodwin, 1996]. The U.S. portion of the program (US-ITASE) is a collaboration of more than a dozen academic and government institutions focused on the West Antarctic Ice Sheet [Mayewski, 2003]. During the austral summer field seasons of 1999-2002, US-ITASE conducted a series of overland traverses throughout West Antarctica and extending to the South Pole, each starting at Byrd Surface Camp $\left(80^{\circ} \mathrm{S}, 120^{\circ} \mathrm{W}\right)$ (Figure 1a). In 2002, along the traverse to South Pole, US-ITASE collected a $72 \mathrm{~m}$ ice core at Hercules Dome and recorded ground-based radioecho sounding data of the bedrock topography and ice stratigraphy to develop the glaciological context of the site.

\section{Geophysical Setting}

[7] During the three days the US-ITASE traverse spent at the Hercules Dome site we completed some $120 \mathrm{~km}$ of GPS and radar profiling in a grid pattern approximately 5 by $50 \mathrm{~km}$ and roughly perpendicular to the main traverse route (Figure 1b). Differential GPS observations utilized a roving base station traveling with the radar system and a base station recording at the US-ITASE drill site (02-4). After postprocessing the data are accurate to $\pm 0.023 \mathrm{~m}$ horizontal and $\pm 0.035 \mathrm{~m}$ vertical in this region [Hamilton and Spikes, 2004]. The dome summit has an elevation of $2610 \mathrm{~m}$ relative to the ellipsoid and appears from our GPS observations to have somewhat less relief in the east-west direction than indicated by the RAMP DEM (Figure 2). Because the nadir altimeter observations of RADARSAT do not extend beyond about $81.5^{\circ} \mathrm{S}$, elevations for the DEM must be interpolated from other sources, sometimes giving rise to imprecise results at the far southern latitudes [Liu et al., 1999].

[8] Radar surveys were conducted using an impulse radar with center frequency of $\sim 3 \mathrm{MHz}\left(\lambda_{\text {ice }}=56 \mathrm{~m}\right)$ and a bandwidth of approximately $1 \mathrm{MHz}$, configured for the heavy traverse operation. Details of the system that was used throughout the US-ITASE project are described by Welch and Jacobel [2003]. Figure 3 shows results from the three main profiles in the vicinity of Hercules Dome (Figure 1b). Bed topography and internal stratigraphy 

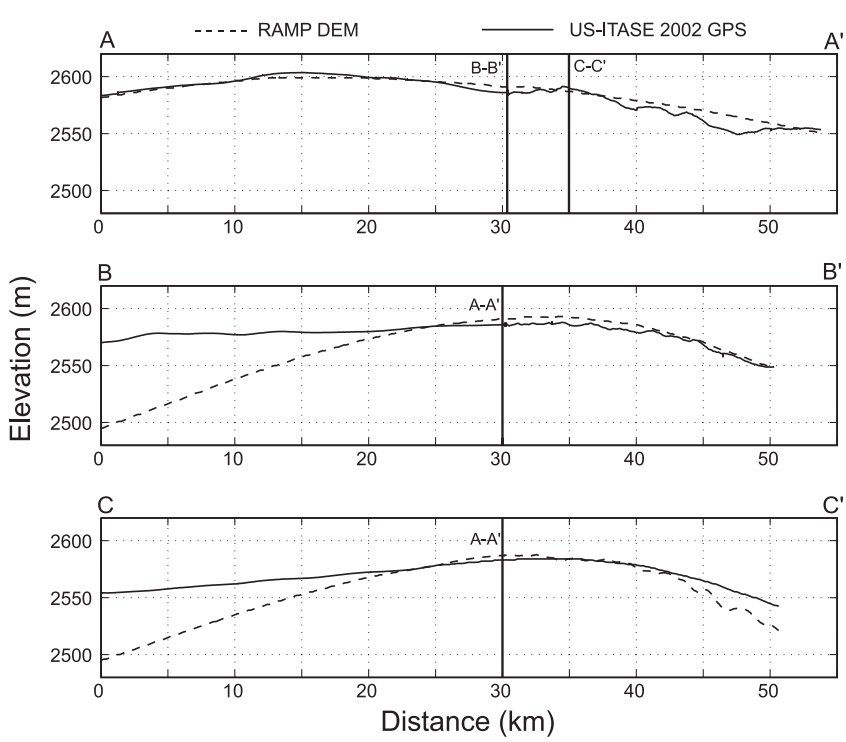

Figure 2. Hercules Dome surface topography from the RAMP DEM and US-ITASE GPS results. RAMP DEM shows greater relief in the cross-dome direction (profiles

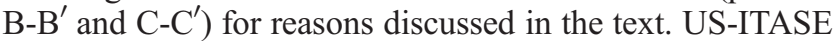
drill site $02-4$ is located at the intersection of $\mathrm{A}-\mathrm{A}^{\prime}$ and $\mathrm{B}-\mathrm{B}^{\prime}$.

down to $70 \%$ of the deepest ice thickness are well depicted in these surveys and we have identified the bed and a number of prominent, continuous internal layers. A high-resolution version of Figure 3 showing greater detail is available online (http://www.stolaf.edu/other/cegsic/publications/JGR_2005/ Figure3.pdf). These data reveal that Hercules Dome is approximately centered over a bedrock low, possibly a basin, some $30-50 \mathrm{~km}$ in extent (Figure 4). The greatest ice thickness under the dome area is $2800 \mathrm{~m}$ with bedrock elevations $200 \mathrm{~m}$ below sea level. Within $15-25 \mathrm{~km}$ in each of the directions surveyed, the bed rises $900-1400 \mathrm{~m}$ from the low under the dome. It is an interesting glaciological question how a dome might develop over a topographic low. One possibility is that ice flow through this region is restricted by the topography and the dome develops as the result of excess accumulation. BEDMAP depictions of the bed topography of the area [Lythe et al., 2001] are derived from grid lines spaced approximately $50 \times 100 \mathrm{~km}$ apart from the SPRI-NSF-TUD survey (see Figure 1a), none of which cross the region we have surveyed. It is therefore not surprising that details of the bed topography were not previously known (Figure 5).

[9] Internal stratigraphy (Figure 3 and interpreted in Figure 5) is well behaved throughout the dome region, in contrast to nearby areas along the traverse route that show marked disruptions of internal layers [Welch et al., 2003]. The pattern of ice deformation revealed by the internal layers mimics the bed topography with muted amplitudes in the relief as layers approach the surface. Also, the constant spacing of layers observed in shallow radar profiles indicates no recent changes in surface accumulation patterns (S. Arcone, personal communication, 2004). Although model studies will be required to explore details more fully, it appears that ice in the vicinity of the dome is frozen to the bed and that ice flow has not undergone major changes throughout at least the period of time represented by the upper $2000 \mathrm{~m}$ of ice thickness.

[10] One of the internal layers, the third from the bottom (Figure 5), has been traced to Byrd Station where it is dated from the Byrd Core at 17.4 kyr B.P. (from GISP2 chronology in Blunier and Brook [2001]). This particular layer is notable because throughout portions of the traverse it is unusually bright, in some areas near Byrd Station brighter than the bed reflection, even though it generally lies at depths greater than half the ice thickness. Hammer et al. [1997] found a spike of excess acid ( $\mathrm{HF}$ and $\mathrm{HCl}$ ) more than 20 times greater than anywhere else in the Byrd core at a depth corresponding to this layer, so it likely resulted from a large eruptive event, though the source is still uncertain. The depth of the layer at both locations is approximately the same, about $1300 \mathrm{~m}$, but the ice thickness at Hercules Dome is greater, about $2800 \mathrm{~m}$. These values may be used in a flow model to give an estimate of the average accumulation rate since the LGM. The model, from Siegert et al. [2003], uses a least squares technique to solve for the accumulation rate by minimizing differences between calculated and measured internal layer architecture. Results give an average value of accumulation of 0.09 to $0.11 \mathrm{~m} / \mathrm{yr}$ (ice equivalent thickness) since the LGM (R. Hindmarsh, personal communication, 2004). This value includes millennia during the LGM when accumulation rate was presumably somewhat lower than the average as well as those closer to the present when it was higher. As an example, a simple Dansgaard-Johnsen flow model [Dansgaard and Johnsen, 1969] optimized to the same vertical strain history and $1300 \mathrm{~m}$ radar layer age, but assuming a step change in accumulation at the glacial/ Holocene transition (11 kyr B.P., a reasonable approximation based on previous ice core analyses [e.g., Jouzel et al., 1989; see also Steig, 1997], suggests an average full glacial value of $0.05 \mathrm{~m} / \mathrm{yr}$ and an average Holocene value of $0.15 \mathrm{~m} / \mathrm{yr}$ (ice equiv.). These flow models also suggest that the age of the ice $200 \mathrm{~m}$ above the bedrock will be in excess of 100,000 years.

[11] Uncertainties in these accumulation rate calculations derive primarily from the model assumptions of steady state flow. Some assurance that these conditions are at least approximately met at Hercules Dome can be gained from considering the development of the "Raymond bump" under the divide. This characteristic upwarp in the internal layers under a stable divide [Raymond, 1983] results from a vertical strain rate that is proportional to ice thickness, unlike flow on the flanks where it is nearly constant with depth in the upper portion of the ice sheet. For example, in Figure 5, profile B-B' ${ }^{\prime}$ shows the presence of a well-developed Raymond bump in the internal stratigraphy at $\mathrm{km} 24$ a few kilometers from where the profile crosses the divide. We are in the process of investigating this Raymond bump in more detail with numerical modeling, but several observations may be made at this point. The bump clearly does not arise from a feature in the bedrock topography, it has the right size and shape and the variation of its amplitude with depth (the fact that it is largest toward the middle of the layers) is consistent with what one expects for a Raymond bump. This pattern suggests that the divide has not migrated horizontally in this dimension [Nereson and Waddington, 2002] and is 

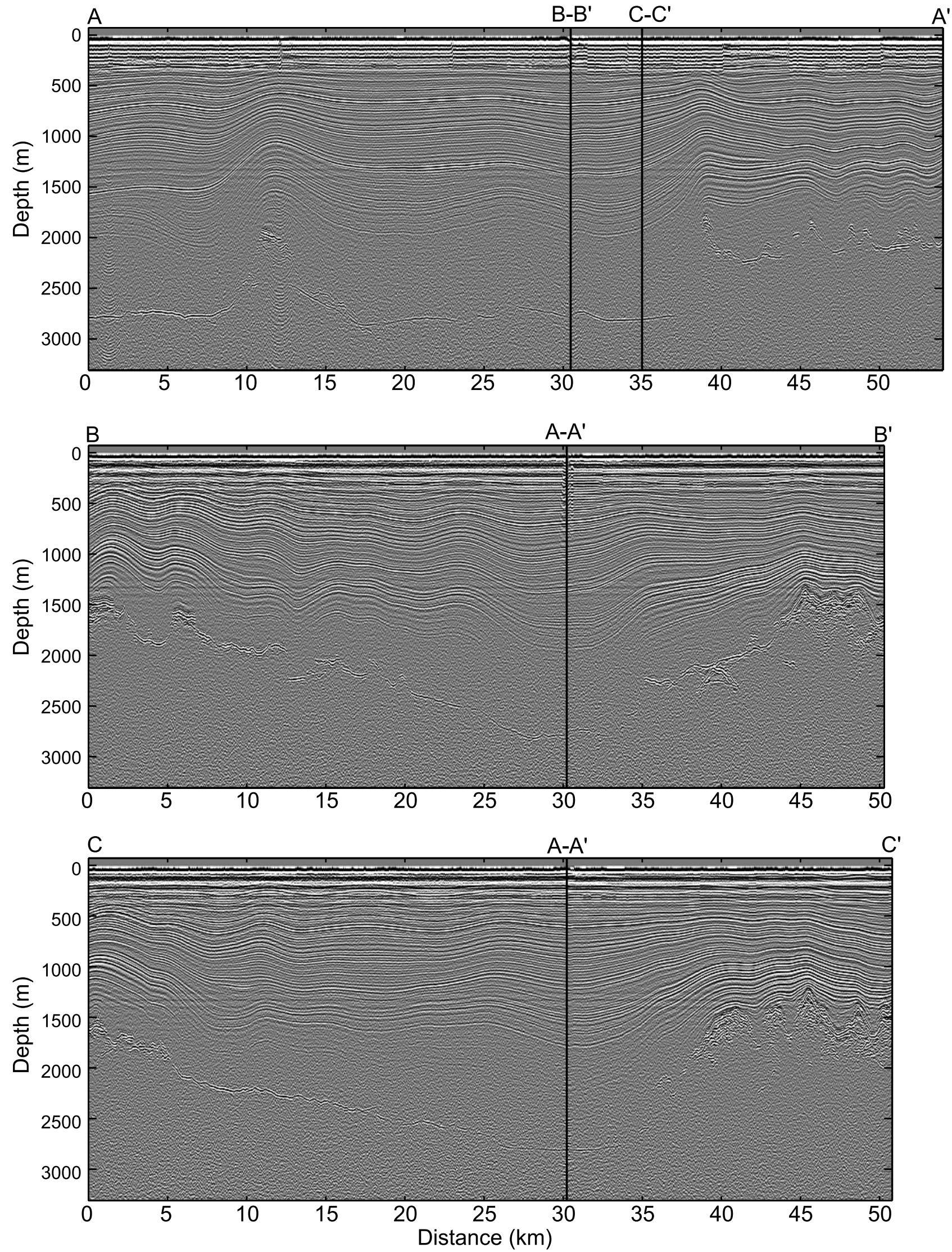

Figure 3. Radar results from the three main profiles (Figure 1b) depicting bedrock echoes and internal stratigraphy for profiles $\mathrm{A}-\mathrm{A}^{\prime}, \mathrm{B}-\mathrm{B}^{\prime}$, and $\mathrm{C}-\mathrm{C}^{\prime}$ shown in Figure $1 \mathrm{~b}$. Vertical exaggeration is approximately $6 \times$. 


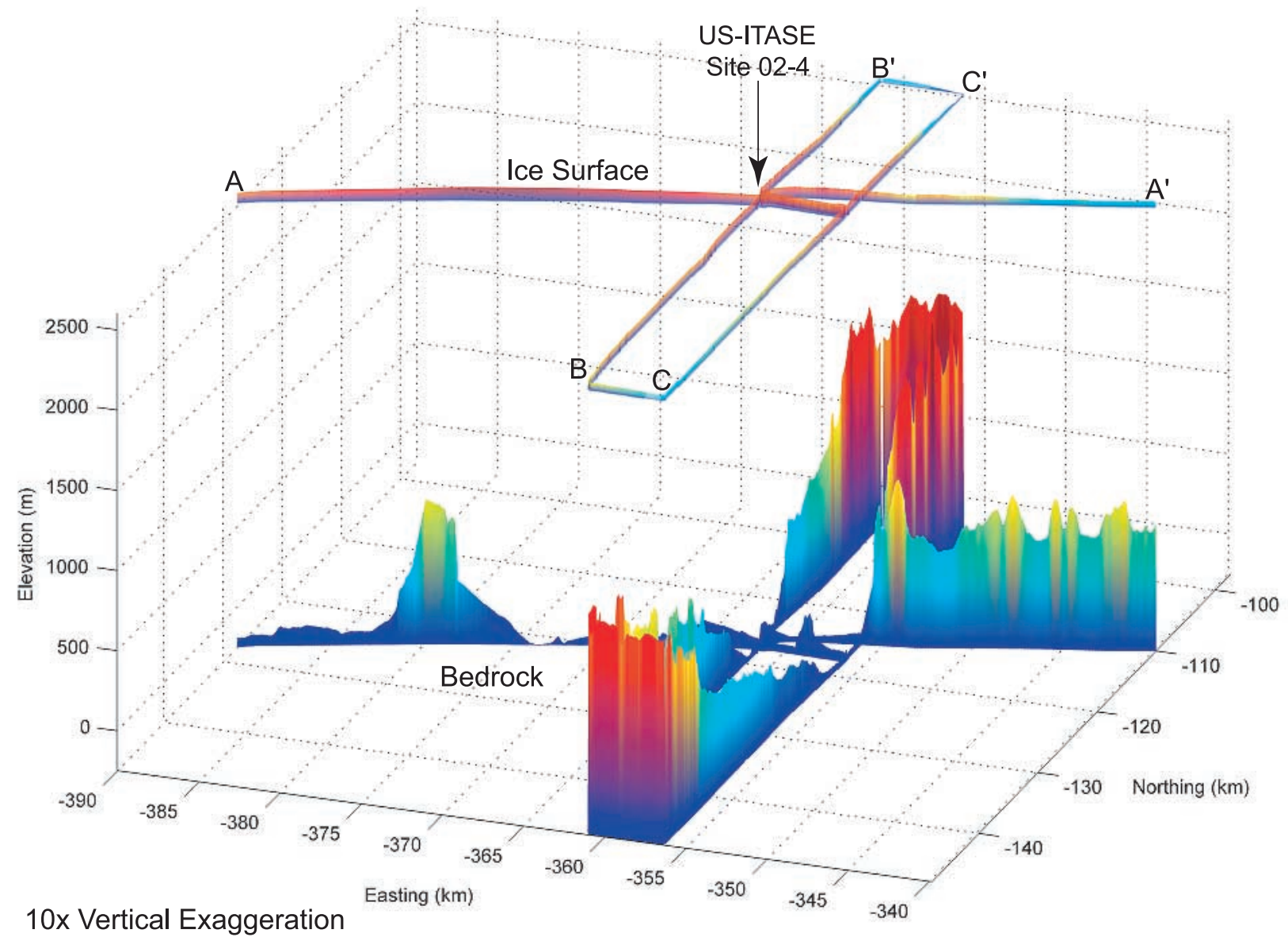

Figure 4. Bed and ice surface interpretation of the Hercules Dome area based on US-ITASE radar and GPS results. Bedrock topography rises in all directions away from the dome center, suggesting that a bed depression, possibly a basin, lies beneath. Color represents the relative elevation along the bedrock and ice surfaces.

further evidence that ice has remained frozen to the bed [Pettit et al., 2003].

\section{Climatic Context}

[12] Although there are no meteorological data available directly from Hercules Dome, we can use the satellite-based record of temperature to examine controls on climate variability at this location. On monthly to decadal timescales, and perhaps on longer timescales as well, Antarctic surface temperature anomalies are spatially heterogeneous. Several recent studies have shown that the bulk of this variability can be successfully explained in terms of largescale atmospheric circulation patterns defined by the principal modes of Southern Hemisphere sea level pressure or tropospheric geopotential height fields. In particular, the Southern Annular Mode (SAM) or Antarctic Oscillation (AAO), defined as the first principal component of $500 \mathrm{hPa}$ geopotential height anomalies [Thompson and Wallace, 2000] is significantly correlated with the first principal component of Antarctic temperature [Schneider et al., 2004]. A trend in the SAM index over the last two decades accounts for a significant fraction of the observed summertime temperature trend in Antarctic weather station data [Kwok and Comiso, 2002; Thompson and Solomon, 2002].
[13] Schneider et al. [2004] have further shown that regional variations in Antarctic temperature are closely associated with the higher-order modes of $20^{\circ}-90^{\circ} \mathrm{S}$ $500 \mathrm{hPa}$ geopotential height anomalies. The pattern of alternating low- and high-pressure anomalies between the western South Pacific and the western South Atlantic, known as the "Pacific South America" (PSA) pattern, is important to West Antarctic climate variability. Owing to the modulation of the PSA pattern by El Niño activity in the tropical Pacific [Bromwich et al., 2004a; Venegas, 2003], there is also a strong El Niño imprint in West Antarctic climate and in areas of East Antarctica closest to West Antarctica. Several studies have reported correlations between ice core geochemical properties and the occurrence of El Niño events [e.g., White et al., 1999; Bromwich and Rogers, 2001; Meyerson et al., 2002].

[14] It has been suggested, from these observations, that ice core records could provide useful paleoclimate information on Pacific ocean climate variability on long timescales $[I C W G, 2003]$, a question of fundamental importance to understanding how El Niño responds to climate forcing (e.g., anthropogenic $\mathrm{CO}_{2}$ emissions) [e.g., Tudhope et al., 2001]. The challenge in using ice core records in this way is that the fraction of local climate variability that can actually be attributed to a particular large-scale climate mode is 

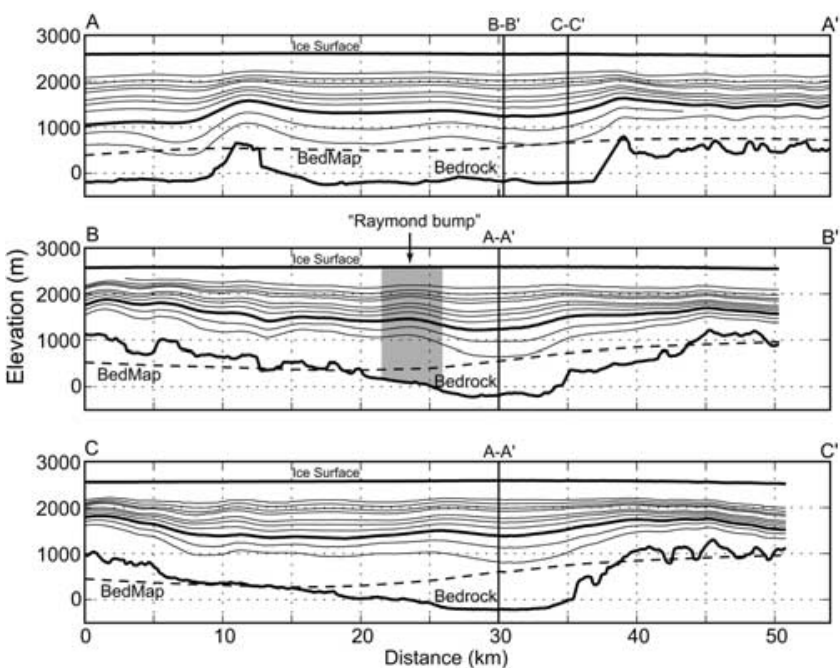

Figure 5. Interpretation of US-ITASE radar reflections for bed topography and internal layer stratigraphy. BEDMAP bed topography [Lythe et al., 2001] is shown for comparison (dashed line). The locations of NSF/SPRI airborne radar soundings used to create BEDMAP are shown in Figure 1b. The third internal layer above the bed (darker line) has been traced to the Byrd Core where it is dated at $17.5 \mathrm{KaBP}$. The Raymond bump is highlighted in the $\mathrm{B}-\mathrm{B}^{\prime}$ profile. Elevation is calculated with respect to the WGS84 datum.

generally quite small, and multiple ice core records would likely be required to obtain climate reconstructions that are statistically robust. In this context, it is illustrative to consider the large-scale context in which local climate variability occurs at Hercules Dome. Figure 6a shows the covariance of local temperature anomalies (from infraredwavelength satellite observations [Comiso, 2000]) with $500 \mathrm{hPa}$ geopotential heights from NCEP/NCAR operational weather forecast reanalysis data. The resulting anomaly pattern resembles a combination of those associated with the SAM and with the Southern Oscillation Index (SOI) [cf. Schneider et al., 2004, Figures 6b, 8, 9b]. Figure $6 \mathrm{~b}$ shows the covariance between the SOI and monthly Antarctic surface temperatures anomalies. Together, these figures suggest that Hercules Dome is one of the more sensitive sites with respect to tropical Pacific climate variability. Indeed, the covariance of SOI with temperature at Hercules Dome is comparable to that at Roosevelt Island, and of opposite sign, suggesting cores from both these localities could possibly provide a robust indicator of SOI variability. In contrast, the expected location of the next deep ice core from West Antarctica, shows no significant covariance with the SOI. We caution, however, that this interpretation of Figure $6 \mathrm{~b}$ makes the implicit assumption that ice core properties (e.g., isotope ratios) show the same patterns of covariance as temperature, which is an imperfect approximation [e.g., Noone and Simmonds, 2002].

\section{Ice Core Results}

[15] In December 2002, a $72 \mathrm{~m}, 82 \mathrm{~mm}$ diameter ice core (US-ITASE 02-4) was obtained at the Hercules Dome site (see Figure 1b) as part of the traverse from Byrd Camp to the South Pole. The entire length of the core has been sampled at a resolution of $\sim 2 \mathrm{~cm}$ for stable isotope and geochemical analyses. Deuterium/hydrogen ratios were

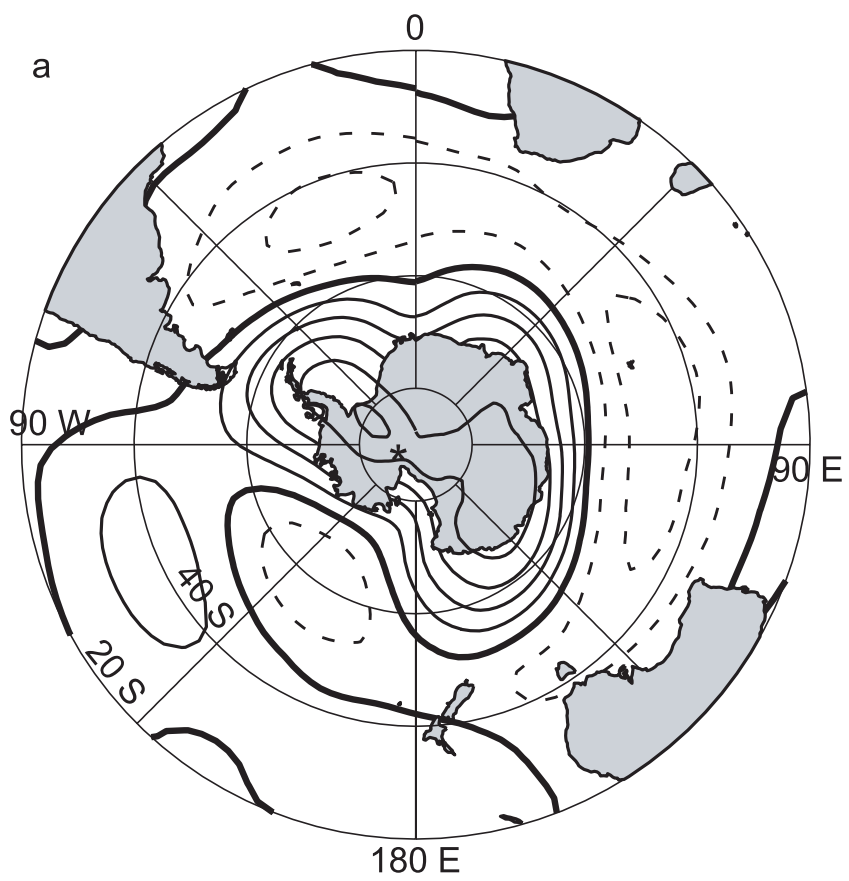

b
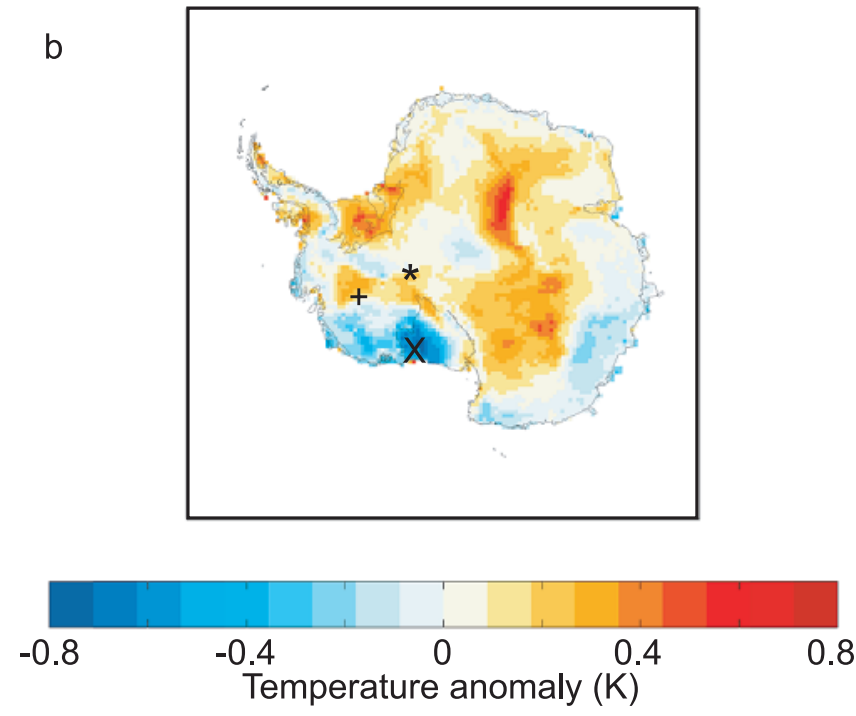

Figure 6. (a) Covariance of $500 \mathrm{hPa}$ geopotential height anomalies with surface temperature at Hercules Dome, based on 1982-1999 monthly averages. The units are meters, with a contour interval of $5 \mathrm{~m}$. The zero contour is bold, positive contours are solid, and negative contours are dotted. $500 \mathrm{hPa}$ data are from the NCEP-NCAR Reanalysis [Kalnay et al., 1996; Kistler, 2001]. Temperature data are from Comiso [2000]. (b) Covariance of Antarctic surface temperatures with the Southern Oscillation Index (SOI). The coloring indicates the magnitude of an anomaly associated with one positive standard deviation of the SOI. The locations of the "Inland Divide" site, Roosevelt Island, and Hercules Dome are indicated by the plus, cross, and asterisk, respectively. 

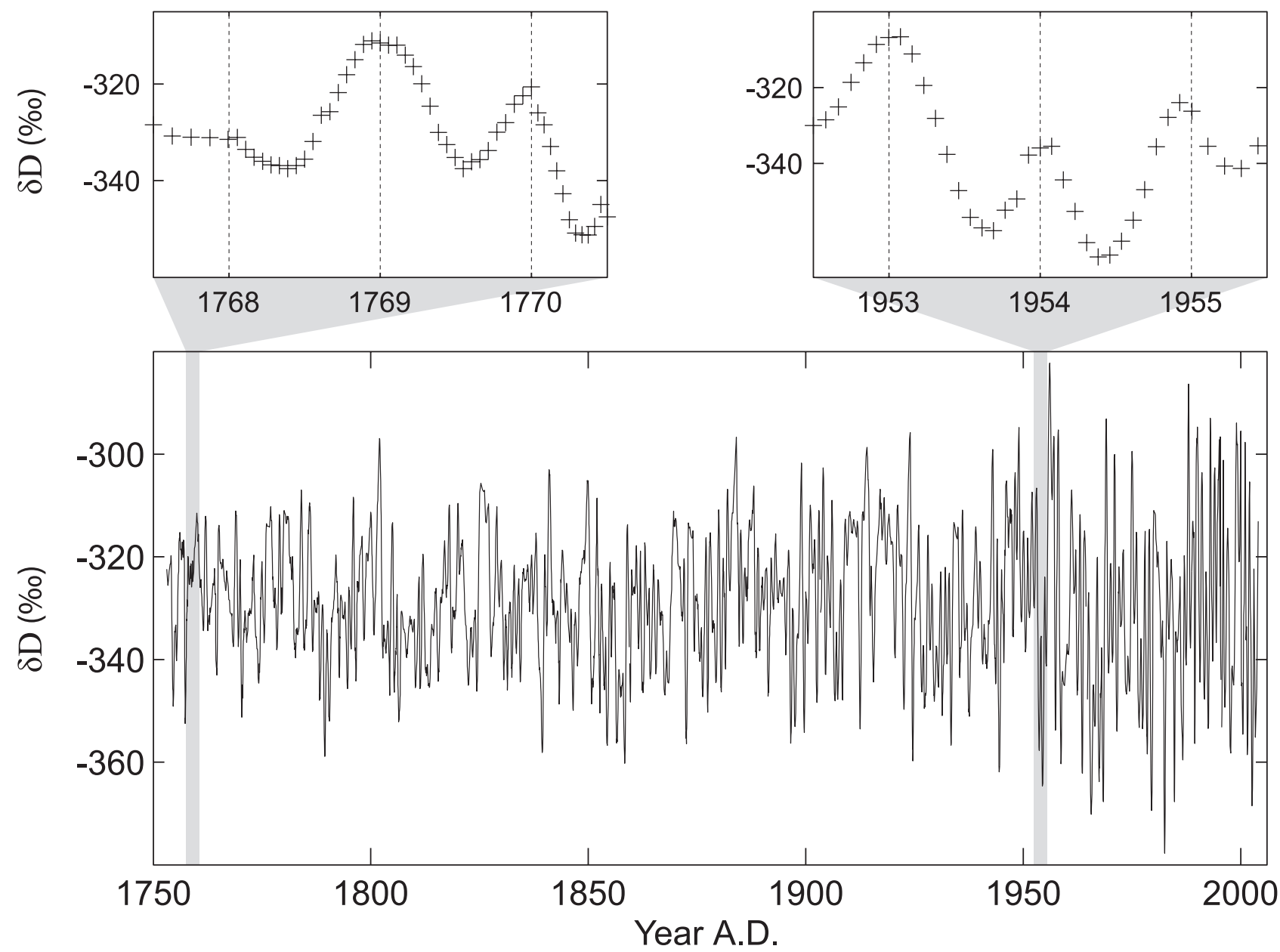

Figure 7. Stable isotope record $(\delta D)$ from Hercules Dome, US-ITASE Core 02-4, versus year. The smaller panels show selected sections to illustrate the annual layer counting.

analyzed with a ThermoFinnigan DeltaPlus dual inlet mass spectrometer at the University of Washington, using a reducing oven with hot $\mathrm{Cr}$ at $850^{\circ} \mathrm{C}$ to convert melted ice samples to $\mathrm{H}_{2}$. Analytical precision is $<0.7 \%$ and analyses are reported as $\delta D$, in parts per thousand (\%o) deviation from Vienna Standard Mean Ocean Water (V-SMOW). The $\delta D$ record exhibits detectable seasonal cycles through the entire core (Figure 7), providing a means to obtain a provisional timescale by annual layer counting. The estimated age at a depth of $72 \mathrm{~m}$ is 250 years before present (i.e., A.D. 1755), which gives a mean accumulation rate of $\sim 0.20 \mathrm{~m} / \mathrm{yr}$ ice equivalent, with a standard deviation of $0.08 \mathrm{~m} / \mathrm{yr}$. Because isotope diffusion reduces the amplitude of seasonal peaks, and can make it difficult to unambiguously identify annual layers, we have the most confidence in the upper $\sim 25 \mathrm{~m}(\sim 100$ years $)$ of the record, above which there is no obvious loss of the seasonal amplitude. Restricting our estimate of annual accumulation to this depth gives a mean accumulation of $0.16 \mathrm{~m} / \mathrm{yr} \pm 0.04$, in excellent agreement with the estimate from the flow models tuned to the depth of the bright radar layer discussed above.

[16] The stable isotopes of water (both $\delta D$ and the more commonly reported $\delta^{18} \mathrm{O}$ ) are important climate proxies that are commonly interpreted in terms of temperature
[Jouzel et al., 1997]. It has been suggested from general circulation model simulations that at least on interannual timescales, isotope variability is perhaps better thought of as a function of large-scale atmospheric circulation anomalies [Noone and Simmonds, 2002]. The results of Schneider et al. [2005] appear to confirm this for West Antarctic ice cores obtained by the US-ITASE program, showing that while the correlation with local mean temperature (obtained from infrared brightness temperatures $\left[\right.$ Comiso, 2000]) is very high on a seasonal basis $\left(r^{2}>0.9\right)$, it is low and statistically insignificant on interannual timescales. On the other hand, correlation with large-scale indices of Antarctic climate is generally significant. For Hercules Dome, covariance between annual mean isotope anomalies and the SOI is significant $(r=0.32, p=0.02$ and $r=0.28$, $p=0.07$ for detrended and raw data, respectively, 19582002). The sign of the observed correlation with the SOI is consistent with the expected sign from the temperature anomaly data (Figure 6), with positive SOI (e.g., La Niña) years corresponding with warm temperatures and enriched (high $\delta D$ ) snowfall. This supports the suggestion that this site is well situated for studies of the relationship between low-latitude Pacific and Antarctic climate variability. We reiterate however, that the correlations are low and multiple ice cores would need to be used together to 
extract statistically robust information on interannual climate variability in the past [Schneider et al., 2005].

\section{Discussion}

[17] The well-behaved internal stratigraphy implies that Hercules Dome has been relatively stable at least in the recent past and possibly for a long time. The fact that internal layers are conformal with bed topography to the deepest depths detected (about $70 \%$ of ice thickness) and that the site lies over a bed depression filled with ice 2800 m thick, suggests that Hercules Dome may be a good location for obtaining very old and undeformed ice at depth. Also, the existence of at least one prominent internal reflector at $17.5 \mathrm{KY}$ that has been traced to widespread locations throughout West Antarctica provides a way to directly tie records at Hercules Dome to ice cores drilled elsewhere.

[18] An ice core from Hercules Dome, if it can be well dated, would be a valuable complement to existing records from other ice core sites. Multiple ice cores are clearly needed for documenting the spatial complexity of past climate variability on short (interannual to decadal timescales) [e.g., King and Comiso, 2003]. It has also has been suggested that dominant features of atmospheric variability on interannual timescales have a role to play on longer timescales. For example, there is some evidence for a pattern in the distribution of Antarctic isotope variations during the Little Ice Age consistent with the SAM in surface temperatures and winds [Steig and Schneider, 2002; Moseley-Thompson and Thompson, 1991]. There is also theoretical and modeling evidence to suggest lowfrequency changes in the Southern Annular Mode and its Northern Hemisphere counterpart, the Northern Annual Mode [Moritz et al., 2002; Noren et al., 2002; Shindell et al., 2001], perhaps driven by low-frequency changes in the tropical Pacific. Such changes, if they have occurred, should be reflected in particular spatial patterns recorded in Antarctic ice cores. Testing such ideas will require more, better dated deep ice cores than are currently available.

[19] The Holocene accumulation rate at Hercules Dome inferred from the stable isotope profile $(0.16-0.2 \mathrm{~m} / \mathrm{yr})$ and the long-term radar record $(\sim 0.09-0.15 \mathrm{~m} / \mathrm{yr})$ suggests accumulation as high or higher than indicated by previous estimates [Vaughan et al., 1999; Bromwich et al., 2004b]. Results from US-ITASE cores in West Antarctica suggest that this is high enough that we can expect excellent preservation of seasonal variations both in stable isotopes and in major ion chemistry. Accumulation rates as determined in the various US-ITASE cores analyzed to date range from range from $\sim 0.08-0.40 \mathrm{~m} / \mathrm{yr}$ [Kaspari et al., 2005]. Even the lowest accumulation cores show clear seasonal variations, which are demonstrably preserved for all years since the geochemical marker horizon provided by identification of the 1815 Tambora volcanic eruption [Dixon et al., 2005], allowing for a dating accuracy better than \pm 1 year [Steig et al., 2005]. The colder temperatures at Hercules Dome, compared to the other US-ITASE sites, may be expected to enhance rather than hinder such preservation, particularly for temperature-sensitive compounds such as stable isotopes and volatile compounds such as nitrate and hydrogen peroxide (see, e.g., Cuffey and
Steig [1998] and Hütterli et al. [2002] for estimates of the temperature and accumulation rate dependences).

[20] Hercules Dome is also promising from the point of view of measurements of atmospheric trace gases trapped in air bubbles, because this is one of the few locations on the high East Antarctic plateau with relatively high accumulation. We may expect, in particular, that isotopic and molecular ratio anomalies in gas bubbles that arise from rapid climate change events will be well preserved at this site. To date, the only evidence of rapid climate change events in Antarctica rivaling those observed in Greenland ice cores is a single event at Siple Dome occurring at about $20 \mathrm{ka}$ [Taylor et al., 2004] that appears to be only of local climatic significance. It is quite possible that events have occurred that affected other areas of the continent and have not been observed because accumulation rates are too low elsewhere (Law Dome [Morgan et al., 2002] is an exception but the record is too short in length to resolve the 20 ka event). A Hercules Dome ice core could thus provide important insights into the long-term behavior of Southern Hemisphere climate.

[21] Acknowledgments. We would like to thank our colleagues on the US-ITASE traverse and to acknowledge the support in the field of those from Raytheon Polar Support Corporation. This work was supported by National Science Foundation grants OPP-9814574 (Jacobel) and OPP-0196105 (Steig).

\section{References}

Ackert, R. P., Jr., D. J. Barclay, H. W. Borns Jr., P. E. Calkin, M. D. Kurz, E. J. Steig, and J. L. Fastook (1999), Measurements of past ice sheet elevations in interior West Antarctica, Science, 286, 276-280.

Blunier, T., and E. Brook (2001), Timing of millennial-scale climate change in Antarctica and Greenland during the last glacial period, Science, 291, $109-112$

Bromwich, D. H., and A. N. Rogers (2001), The El Niño-Southern Oscillation modulation of West Antarctic precipitation, Antarct. Res. Ser. $77,91-104$

Bromwich, D. H., A. J. Monaghan, and Z. Guo (2004a), Modeling the ENSO modulation of Antarctic climate in the late 1990s with Polar MM5, J. Clim., 17, 109-132.

Bromwich, D. H., Z. Guo, L. Bai, and Q.-S. Chen (2004b), Modeled Antarctic precipitation. part I: Spatial and temporal variability, J. Clim., $17,427-447$

Caillon, N., J. P. Severinghaus, J. Jouzel, J. M. Barnola, J. Kang, and V. Y. Lipenkov (2003), Timing of atmospheric $\mathrm{CO}_{2}$ and Antarctic temperature changes across Termination-III, Science, 299, 1728-1731.

Comiso, J. C. (2000), Variability and trends in Antarctic surface temperatures from in situ and satellite infrared measurements, J. Clim., 13, $1674-1696$.

Cuffey, K. M., and E. J. Steig (1998), Isotope diffusion in polar firn: Implications for interpretation of seasonal climate parameters in ice core records, with emphasis on central Greenland, J. Glaciol., 44, 273-284.

Dansgaard, W., and S. J. Johnsen (1969), A flow model and a time scale for the ice core from Camp Century, Greenland, J. Glaciol., 8, 215-223.

Dixon, D., P. A. Mayewski, S. Sneed, M. A. Handley, P. A. Sneed, and S. Handley (2005), 200-year West Antarctic paleoclimate record from U.S. ITASE ice cores, Ann. Glaciol., in press.

Hamilton, G. S., and V. B. Spikes (2004), Evaluating a satellite altimeterderived elevation model of Antarctica using precision kinematic GPS profiling, Global Planet. Change, 42, 17-30, doi:10.1016/j.gloplacha. 2003.11.002.

Hammer, C. U., H. B. Clausen, and C. C. Langway Jr. (1997), 50,000 years of recorded global volcanism, Clim. Change, 35, 1-15.

Hütterli, M. A., R. C. Bales, J. R. McConnell, and R. W. Stewart (2002), $\mathrm{HCHO}$ in Antarctic snow: Preservation in ice cores and air-snow exchange, Geophys. Res. Lett., 29(8), 1235, doi:10.1029/2001GL014256.

Ice Core Working Group (1988), Compiled reports of the U.S. Ice Core Research Workshop, June 13-17, 1988, Durham, N. H.

Ice Core Working Group (1989), U.S. Global Ice Core Research Program, West Antarctica and beyond, report, Durham, N. H.

Ice Core Working Group (2003), U.S. ice core science: Recommendations for the future, report, Durham, N. H. 
Jouzel, J., G. Raisbeck, J. P. Benoist, F. Yuiou, C. Lorious, D. Raynaud, J. R. Petit, N. I. Barkov, Y. S. Korotkevitch, and V. M. Kotlyakov (1989), A comparison of deep Antarctic ice cores and their implications for climate between 65000 and 15000 years ago, Quat. Res., 31, 135 150

Jouzel, J., et al. (1997), Validity of the temperature reconstruction from water isotopes in ice cores, J. Geophys. Res., 102, 26,471-26,487.

Kalnay, E., et al. (1996), The NCEP-NCAR 40-Year Reanalysis Project, Bull. Am. Meteorol. Soc., 77, 437-472.

Kaspari, S., P. A. Mayewski, S. Sneed, and M. Handley (2005), West Antarctic climate reconstruction based on the 2001-2002 U.S. ITASE ice cores, Ann. Glaciol., in press.

King, J. C., and J. C. Comiso (2003), The spatial coherence of interannual temperature variations in the Antarctic Peninsula, Geophys. Res. Lett., 30(2), 1040, doi:10.1029/2002GL015580.

Kistler, R (2001), The NCEP-NCAR 50-Year Reanalysis: Monthly means CD-ROMS and documentation, Bull. Am. Meteorol. Soc., 82, 247-268.

Kwok, R., and J. C. Comiso (2002), Spatial patterns of variability in Antarctic surface temperature: Connections to the Southern Hemisphere Annular Mode and the Southern Oscillation, Geophys. Res. Lett. 29(14), 1705, doi:10.1029/2002GL015415.

Liu, H., K. Jezek, and B. Li (1999), Development of an Antarctic digital elevation model by integrating cartographic and remotely sensed data: A geographic information system based approach, J. Geophys. Res., 104, $23,199-23,213$

Lythe, M. B., D. G. Vaughan, and BEDMAP Consortium (2001), BEDMAP: A new ice thickness and subglacial topographic model of Antarctica, J. Geophys. Res., 106, 11,335-11,352.

Martinérie, P., V. Y. Lipenkov, D. Raynaud, J. Chappellaz, N. I. Barkov, and C. Lorius (1994), Air content paleo record in the Vostok ice core (Antarctica): A mixed record of climatic and glaciological parameters, J. Geophys. Res., 99, 10,565-10,576.

Mayewski, P. A. (2003), Antarctic oversnow traverse-based Southern Hemisphere climate reconstruction, EOS Trans. AGU, 84(12), 205

Mayewski, P. A., and I. D. Goodwin (1996), US ITASE: Science and implementation plan, report, 52 pp., Univ. of N. H., Durham.

Meyerson, E. A., P. A. Mayewski, S. I. Whitlow, L. D. Meeker, K. J. Kreutz, and M. S. Twickler (2002), The extratropical expression of ENSO recorded in a South Pole glaciochemical time series, Ann. Glaciol., 39, XX-XX

Morgan, V., M. Delmotte, T. van Ommen, J. Jouzel, J. Chappellaz, S. Woon, V. Masson-Delmotte, and D. Raynaud (2002), Relative timing of deglacial climate events in Antarctica and Greenland, Science, 297, $1862-1864$

Moritz, R. E., C. E. Bitz, and E. J. Steig (2002), Dynamics of recent climate change in the Arctic, Science, 297, 1497-1502.

Mosley-Thompson, E., and L. G. Thompson (1991), Spatial and tempora characteristics of the Little Ice Age: The Antarctic ice core record, in The Role of the Polar Regions in Global Change, edited by G. Weller, pp. 606-610, Geophys. Inst. Univ. of Alas., Fairbanks.

Nereson, N., and E. D. Waddington (2002), Isochrones and isotherms beneath migrating ice divides, J. Glaciol., 48, 95-108.

Noone, D., and I. Simmonds (2002), Annular variations in moisture transport mechanisms and the abundance of $\delta^{18} \mathrm{O}$ in Antarctic snow, J. Geophys. Res., 107(D24), 4742, doi:10.1029/2002JD002262.

Noren, A. J., P. R. Bierman, E. J. Steig, A. Lini, and J. A. Southon (2002), Millennial-scale storminess variability in the northeastern United States during the Holocene, Nature, 419, 821-824.

Pettit, E., H. P. Jacobson, and E. D. Waddington (2003), Effects of basa sliding on isochrones and flow near an ice divide, Ann. Glaciol., 37, $370-376$

Raymond, C. F. (1983), Deformation in the vicinity of ice divides, J. Glaciol., 29, 357-373.

Raynaud, D., and I. M. Whillans (1982), Air content of the Byrd core and past changes in the West Antarctic Ice Sheet, Ann. Glaciol., 3, 269273
Schneider, D. P., E. J. Steig, and J. Comiso (2004), Recent climate variability in Antarctic from satellite-derived temperature data, J. Clim., 17, $1569-1583$

Schneider, D. P., E. J. Steig, and T. van Ommen (2005), Interpretation of high resolution stable isotope records from Antarctica, with implications for climate reconstructions, Ann Glaciol., in press.

Severinghaus, J. P., and E. J. Brook (1999), Abrupt climate change at the end of the last glacial period inferred from trapped air in polar ice, Science, 286, 930-934.

Shindell, D. T., G. A. Schmidt, M. E. Mann, D. Rind, and A. Waple (2001), Solar forcing of regional climate change during the Maunder Minimum, Science, 294, 2149-2152.

Siegert, M. J., R. C. A. Hindmarsh, and G. S. Hamilton (2003), Evidence for a large region of surface ablation in central East Antarctica during the last ice age, Quat. Res., 59, 114-121.

Steig, E. J. (1997), How well can we parameterize past snow accumulation rates in polar ice sheets?, Ann. Glaciol., 25, 418-422.

Steig, E. J., and D. P. Schneider (2002), Interannual to millennial-scale variability of Antarctic ice sheet climate, Eos Trans. AGU, 83(19), Spring Meet. Suppl., Abstract A41A-12.

Steig, E. J., J. L. Fastook, C. Zweck, I. D. Goodwin, K. J. Licht, J. W. C. White, and R. P. Ackert Jr. (2001), West Antarctic Ice Sheet elevation changes, Antarct. Res. Ser., 77, 75-90.

Steig, E. J., et al. (2005), High-resolution ice cores from US ITASE (West Antarctica): Development and validation of chronologies and determination of precision and accuracy, Ann. Glaciol., in press.

Taylor, K. C., et al. (2004), Abrupt late glacial climate change in the Pacific sector of Antarctica, Quat. Sci. Rev., 23, 7-15.

Thompson, D. W. J., and S. Solomon (2002), Interpretation of recent Southern Hemisphere climate change, Science, 296, 895-899.

Thompson, D. W. J., and J. M. Wallace (2000), Annular modes in the extratropical circulation. part I: Month-to-month variability, J. Clim., $13,1000-1016$

Tudhope, A. W., C. P. Chilcott, M. T. McCulloch, E. R. Cook, J. Chappell, R. M. Ellam, D. W. Lea, J. M. Lough, and G. B. Shimmield (2001), Variability in the El Niño-Southern Oscillation through a glacial-interglacial cycle, Science, 291, 1511-1517.

Vaughan, D. G., J. L. Bamber, M. Gioventto, J. Russel, and A. P. R. Cooper (1999), Reassessment of net surface mass balance in Antarctica, J. Clim., $12,933-946$.

Vaughan, D. G., G. J. Marshall, W. M. Connolley, C. Parkinson, R. Mulvaney, D. A. Hodgson, J. C. King, C. J. Pudsey, and J. C. Turner (2003), Recent rapid regional climate warming on the Antarctic Peninsula, Clim. Change, 60, 243-274.

Venegas, S. A. (2003), The Antarctic Circumpolar Wave: A combination of two signals?, J. Clim., 16, 2509-2525.

Welch, B. C., and R. W. Jacobel (2003), Analysis of deep-penetrating radar surveys of West Antarctica, US-ITASE 2001, Geophys. Res. Lett., 30(8), 1444, doi:10.1029/2003GL017210.

Welch, B. C., R. W. Jacobel, K. A. Christianson, and K. P. Cofell-Dwyer (2003), Interactions between large bedrock features and ice sheet dynamics interpreted from deep-penetrating radar along the US-ITASE traverse routes, Eos Trans. $A G U, 84(46)$, Fall Meet. Suppl., Abstract C21D-02.

White, J. W. C., E. J. Steig, J. Cole, E. R. Cook, and S. J. Johnsen (1999), Recent, annually resolved climate as recorded in stable isotope ratios in ice cores from Greenland and Antarctica, Am. Meteorol. Soc. Symp. Global Clim. Change Stud., 10, 300-302.

R. W. Jacobel and B. C. Welch, Department of Physics, St. Olaf College, 1520 St. Olaf Avenue, Northfield, MN 55057, USA. (jacobel@stolaf.edu; welchb@stolaf.edu)

D. P. Schneider and E. J. Steig, Department of Earth and Space Sciences, University of Washington, Seattle, WA 98195, USA. (schneidd@ u.washington.edu; steig@ess.washington.edu) 